\section{Germany's energy plans}

The West German government presented its latest programme to safeguard Germany's future energy supplies last December. An important feature of the programme concerns the efficient use of energy, especially for use in private households which accounts for the largest share of all Germany's energy consumption.

As heating makes up for $80 \%$ of private consumption, in future all new buildings will be legally required to conform to building regulations aimed at improving insulation. The government is also encouraging private owners to improve the insulation of existing buildings by offering them grants of $25 \%$ of the initial cost of improvement up to DM12,000 per purchase $(£ 1=4 D M)$ over the next five years. The grant also applies to the installation of solar collectors.

The new energy programme is clearly in favour of nuclear energy. Without it, the government feels that it could not guarantee an electricity supply in the long term. But just how much nuclear power station capacity is necessary is a matter of dispute particularly amonst the governing parties.

In future, however, new nuclear power stations will be sanctioned only if the problems of radioactive waste disposal are solved. And the German view is that this can only be done by building a central plant to reprocess the spent fuel elements and to take care of the final disposal of radioactive wastes.

A site for such a plant has been chosen at Gorleben but the local population are protesting about its construction. So at the moment additional storage ponds are being built to store spent fuel elements from the power stations. The basic commitment to nuclear energy of both the federal government and the parties in the Bundestag will, therefore, only be realised if the radioactive waste disposal problem is solved.

However, the German government is also looking to coal for future energy needs. But German pit coal is very expensive and the present production of 90 million tonnes per year can be maintained only with considerable state subvention. Government and industrial research into non-nuclear energy sources is also being strengthened, the conversion of coal into other products being central to the government's programme. Research on alternative energy sources, such as solar and wind energy, is also receiving government support.

Werner Gries

\section{Sighting the Yeti's relatives}

Following reports of a possible "Loch Ness" monster in Lake Kos Kol, Soviet scholars have postulated a possible "relation" of the Yeti. The Institute of Language, Literature, and History of the Yakut Branch of the Academy of Sciences of the USSR has collected numerous accounts of sightings of a creature known locally as the "Chuchunaa", a name which apparently is connected with the Yakut word for "fugitive" or "outcast".

According to informants, the Chuchunaa is over $2 \mathrm{~m}$ tall, uttering deerskin, and is unable to talk, uttering only a piercing whistle. He is described as a meat-eater, and is said to have the habit of creeping up to settlements and stealing food. When the Chuchunaa sights a hunter or reindeer-herder, he usually takes flight, but on occasion, it is said, will pick a fight. (No data have been released as to the outcome of such encounters.)

The best sightings of the Chuchunaa seem to occur in summer at dawn or late dusk. Hunters, mushroom pickers and the like who are out at this time have reported seeing a wild man, with arms hanging below his knees, barefoot and dressed in skins. The face is said to be large, human-like but very dark, with a protruding brow "like a peak", long matted hair, and a full beard-larger than that of a man. At such times, the Chuchunaa has been reported to be feeding on berries, tearing them from the bushes with both hands.

According to Semen Nikolaev, a senior staff member of the Yakut Branch of the Academy, "almost all witnesses speak of the Chuchunaa as a reality without the fantastic detail so characteristic of legends". (To a Westerner, the above description seems very much the stuff of which legends ing whatever Nikolaev would classify as "fantastic"-Baba Yaga riding on her pestle, maybe?). Since the details of many sitings coincide, Nikolaev and his colleagues seem willing to admit the postulate that the Chuchunaa represents the last surviving remnant of the "Palaeoasiatic aborigines" of Siberia, who have retreated to a last refuge in the upper reaches of the Yana and Indigirka rivers. Indeed, since the last reliable sighting dates from the $1950 \mathrm{~s}$, some of the more pessimistic experts think that the Chuchunaa may have died out during the last two decades. are made-and one cannot help wonder-

\section{World Bank's new health commitment}

HAVING for years fought shy of involving itself in activities concerned with health, the World Bank has now taken a second step in the opposite direction - the first being its co-sponsorship of WHO/UNDP Onchocerciasis Control Programme (OCP) in the Volat River Basin. The new commitment was confirmed at a meeting at the beginning of February at WHO Headquarters in Geneva, with a 'memorandum of understanding' between the same three partners as co-sponsors of the Special Programme for Training and Research in Tropical Diseases. In general, the arrangement follows the same lines as that for the OCP, the Bank being responsible for administering the Tropical Diseases Research Fund, contributed by governments and organisations for projects to be executed by WHO and UNDP.

As expected, the cooperating parties' interests will be coordinated by a Joint Consultative Board. The board is expected to hold its first meeting in November this year. Its 30 members will include 12 representatives of governments, selected by the contributors; 12 selected by WHO's Regional Committee from among those countries directly affected by the diseases, or supporting the fund with scientific and technical assistance; three from among cooperating parties not otherwise represented; and one each from three sponsors of the programme. The latter will also have their own standing committee, meeting twice a year, concerned with technical and financial oversight of the programme.

As in the case of the OCP, there will be a scientific and technical advisory committee, concerned not only with advice on these aspects of the programme, but also with continuous independent evaluation of all programme activities. The 15 to 18 members of this committee will serve in their personal capacities, covering the whole range of biomedical and other disciplines with which the programme is concerned. The initial impetus will be maintained by interim meetings of the various groups before their formal establishment in November. A programme coordinator at the headquarters of the WHO will be responsible for the management of the programme.

As to financing, the meeting ended with some $\$ 11$ million pledged by various donors for the current year's activities. Moreover several large donors indicated that they would be making longer term pledges to cover at least the next five years of the programme. Peter Collins 